\title{
Amartya Sen, the World Bank, and the Redress of Urban Poverty: A Brazilian Case Study
}

\author{
ALEXANDRE APSAN FREDIANI \\ Alexandre Apsan Frediani is a Ph.D. researcher at Oxford Brookes \\ University, Department of Planning, Oxford, UK
}

\begin{abstract}
While there is some suggestion of a re-orientation in the World Bank's income-cantered conceptualization of poverty to one based on Amartya Sen's concept of 'development as freedom', it is hard to uncover definitive evidence of such a re-orientation from a study of the Bank's urban programmes in Brazil. This paper attempts an application of Sen's capability approach to the problem of improving the urban quality of life, and contrasts it with the World Bank's approach, with specific reference to a typical squatter upgrading project in Novos Alagados in Salvador da Bahia, Brazil.
\end{abstract}

Key words: Amartya Sen, World Bank, Poverty alleviation, Squatter settlements

\section{Introduction}

Shortage of housing, and increasing expansion of informal settlements, are two of the many challenges that developing countries have to typically cope with. According to the United Nations, the world squatter settlement population of one billion squatter dwellers will double in the next three decades. In Brazil alone, the 2001 national census identified 2362708 households in registered squatter settlements (Instituto Brasileiro de Geografia e Estatística, 2004). Brazilian housing policies have in various ways attempted to tackle the country's housing problem, at least since the 1940s. One of the major donors encouraging and influencing the Brazilian Government in its housing strategies has been the World Bank. ${ }^{1}$

The evolution of policies has reflected changes in the conceptualization of the relation between physical improvements and quality of life. This is evident, for instance, in a movement of policy away from the eradication of squatter settlements and displacement towards legalization of tenure and upgrading. Recently, the World Bank has once again 
reformulated its conceptualization of poverty, apparently on a certain reading of Sen's view of 'development as freedom'. However, it is not clear that this re-conceptualization has overcome the challenge of a low urban quality of life, nor significantly retarded the growth of squatter settlement populations.

This paper will first examine the relationship of international development trends and Brazilian housing policies, followed by a review of how Sen's capability approach might contribute to an understanding of the strategies required for tackling urban poverty, and an assessment of the manner in, and degree to, which the World Bank has adapted Sen's concepts to its urban policies. In the final section, the paper presents some preliminary findings of an evaluation of the World Bank's squatter upgrading programme in Salvador da Bahia, in the light of Sen's capability approach. Specifically, the evaluation reviews the impact of the upgrading programme on six selected freedoms relating to the ability to command dignified shelter. Such an evaluation, it is hoped, will enable an appreciation both of the Bank's interpretation of Sen's concepts, and of the impact of the Bank's programme on the freedom of the city's poor dwellers to emerge from poverty.

\section{Concepts and policies}

The relationship between squatter settlement upgrading and poverty alleviation is both complex and contradictory. Definitional variations in the concepts of poverty and squatter settlements have themselves contributed to changes in the strategies for tackling the problem of inadequate housing. By the end of the 1990s, the World Bank accepted the weaknesses and failures of earlier strategies - which can be characterized, broadly, as 'modernization' (1945-1973), 'basic needs' (1974-1984), and 'neo-liberal' (1985-1999) - and put forward an innovative discourse based on Sen's writings (see Table 1).

The emerging paradigm responded to the neo-liberal approach that had dominated the 1980s and 1990s. Throughout this period, market enablement was the dominant ideology in the World Bank and in Brazil. Following the 1984 Mexican crisis, the concept of poverty widely held by international donors has been based on De Soto's (1989) perception that poverty is a result of the failure to employ market rules effectively. This dualistic interpretation divided the cities of the developing world into formal and informal sectors. Poverty would be a phenomenon associated mainly with the informal sector. Therefore, to tackle poverty, it was necessary - in this view - to integrate the two sectors through policies orientated to increasing competitiveness, and to providing access to credit and technical assistance (Martinez, 1988). In the Washington Consensus of 1989, the US government, together with the World Bank and the International Monetary Fund, consolidated the neo-liberal ideology that was to drive the 1990s urban development strategies: while sponsoring the 
Table 1. From development paradigms to Brazilian housing policies

\begin{tabular}{|c|c|c|c|}
\hline Development strategy & $\begin{array}{l}\text { Concept of poverty } \\
\text { (reference) }\end{array}$ & Housing solutions & $\begin{array}{c}\text { Brazilian housing } \\
\text { policies }\end{array}$ \\
\hline $\begin{array}{l}\text { Modernization } \\
\quad(1945-\text {-end of World } \\
\text { War II) }\end{array}$ & $\begin{array}{l}\text { Culture of poverty } \\
\text { (Lewis, 1966) }\end{array}$ & $\begin{array}{l}\text { Eradication and } \\
\text { provision of } \\
\text { houses on } \\
\text { outskirts of cities }\end{array}$ & $\begin{array}{l}\text { 1964-Military } \\
\text { Government and BNH: } \\
\text { eradication with } \\
\text { reallocation }\end{array}$ \\
\hline $\begin{array}{l}\text { Growth with equity } \\
\text { (1973-oil crisis) }\end{array}$ & $\begin{array}{l}\text { Help the poor to help } \\
\text { themselves (Turner, } \\
\text { 1972) }\end{array}$ & $\begin{array}{l}\text { Site and services, } \\
\text { squatter upgrading }\end{array}$ & $\begin{array}{l}\text { PROMORAR and } \\
\text { PROFILURB: self-help } \\
\text { housing }\end{array}$ \\
\hline $\begin{array}{l}\text { Neo-liberal (1984- } \\
\text { Mexican crisis, } \\
\text { 1989-Washington } \\
\text { Consensus) }\end{array}$ & $\begin{array}{l}\text { Poverty was a result of } \\
\text { the failure to employ } \\
\text { the market effectively } \\
\text { (De Soto, 1989) }\end{array}$ & $\begin{array}{l}\text { Upgrading with } \\
\text { structural } \\
\text { adjustment to } \\
\text { boost the housing } \\
\text { market sector }\end{array}$ & $\begin{array}{l}\text { Regional housing loans } \\
\text { with structural } \\
\text { changes: Novos } \\
\text { Alagados Project }\end{array}$ \\
\hline Emerging paradigm & $\begin{array}{l}\text { New dimensions: } \\
\text { vulnerability, } \\
\text { voicelessness and } \\
\text { powerlessness (Sen, 1999) }\end{array}$ & $\begin{array}{l}\text { Move from housing } \\
\text { sector to city } \\
\text { development } \\
\text { strategy }\end{array}$ & $\begin{array}{l}\text { Scale up of projects to } \\
\text { programme - Ribeira } \\
\text { Azul }\end{array}$ \\
\hline
\end{tabular}

PROMORAR, Programa de Erradicação da Subabitação (Shanty Replacement Programme); PROFILURB, Programa de Financiamento de Lotes Urbanizados (Site and Services Financing Programme).

provision of basic infrastructure and regularization of tenure in squatter settlements, the World Bank encouraged cutting public expenditure through a reconfiguration of state functions that was compatible with minimal state intervention. The ultimate purpose has been to encourage developing countries to join the global market and to generate income to repay their international debts.

The introduction of the neo-liberal agenda in Brazil can be divided into two phases: in the 1980s there were the political and economic reforms necessary to balance the national account and empower the market, while in the 1990s loans became regional with the object of alleviating poverty and improving conditions for the market to work more efficiently. On the one hand, the return in Brazil of the civilian government in 1985 initiated an era of renewed democratization and also decentralization. But, on the other hand, with the financial crisis of the Brazilian Housing Bank (BNH) - Banco Nacional da Habitação - and the breakdown of national housing policies, the World Bank was able to assume a more central role in the formulation of regional housing policies. There was a reduction in national and regional public expenditures. In 1986, the BNH was abolished, and the international deficit was temporarily controlled. Meanwhile poverty and inequality increased. "This period also saw the institutionalisation of much more avowedly market orientated government policies which, although in different ways, have similarly impacted negatively on low income urban dwellers" (De Souza and Zetter, 2004, p. 169). Organized land occupations returned, and the squatter settlements' population increased considerably (Gordilho, 2000). 
By the end of the 1990s, the World Bank began to review its understanding of poverty, and acknowledged that its current upgrading policies were not having a significant impact on the alleviation of poverty. There is some suggestion of a drift on the Bank's part from De Soto's conceptualization of poverty toward one based on the writings of Sen, who believes that "... poverty must be seen as the deprivation of basic capabilities rather than merely as lowness of incomes ..." (Sen, 1999, p. 87). The commitment to operationalize this notion can be clearly seen in the article written by J. D. Wolfensohn (then president of the World Bank) and Sen: "For the World Bank, too, development is a process that ends with freedom from poverty and from other social and economic deprivations" (Wolfensohn and Sen, 1999). Gore (2000) presents a detailed elaboration: a capsule summary is avoided because it carries with it the risk of presenting an oversimplified version of a complex and subtle shift in policy. Even though the controversial 2000/2001 World Development Report ('Attacking Poverty') (World Bank, 2000a) led to the resignation of its director Ravi Kanbur, and exposed disagreements within the Bank, the report does seem to reflect some measure of influence on the Bank's thinking of the notion of 'development as freedom' (Wade, 2001). The report expands the concept of poverty by including dimensions of vulnerability, voicelessness, and powerlessness within its ambit. One would think it legitimate to imagine that this more encompassing way of conceiving poverty would pave the way for a reconfiguration of policies aimed at alleviating it.

Before ascertaining whether the promise held out was fulfilled, it is necessary to examine how Sen's capability approach might be interpreted in, and applied to, the context of squatter upgrading programmes. This should facilitate an assessment of how deeply or otherwise the Bank has internalized the Sen framework of 'development as freedom', as reflected both in its urban policy papers and in one of its upgrading programmes on the ground. In what follows, these two exercises are undertaken in turn.

\section{Sen's approach and squatter intervention}

\section{The capability approach: a background exposition}

Sen's ideas on the 'capability approach' to assessing deprivation and wellbeing have been considered and further developed by a number of scholars working in this field. This is reflected in the evolution of a broad normative framework for the evaluation of individual well-being and social arrangements (Nussbaum, 1988; Sen, 1999; Chiappero Martinetti, 2000; Alkire, 2002; Robeyns, 2003). The core characteristic of the capability approach is to de-emphasize an exclusive preoccupation with income-led evaluation methods, and to focus more generally on the ability people have to achieve the things they value. In this view, well-being can be measured by assessing people's freedom and choices, rather than their 
level of income or consumption. Thus policy design should aim at “... removing obstacles in their [people's] lives so that they have more freedom to live the kind of life which, upon reflection, they find valuable", (Robeyns, 2003, p. 6).

Sen's approach to well-being assessment is based on two concepts: capabilities and functionings. Capabilities are the freedoms people have to achieve the kinds of lives they have reason to value. Those states of doing or being which people value Sen terms as 'functionings'. This approach is based on an Aristotelian tradition, conceptualizing development as a process of expansion of people's freedom to be and do what they may value. "The 'good life' is partly a life of genuine choice, and not one in which the person is forced into a particular life - however rich it might be in other respects" (Sen, 1996, p. 59). Like Aristotle, Sen argues that the doings and beings that people value have not only instrumental but also intrinsic worth. While they are a means to the achievement of well-being, functionings are also ends in themselves. Seen in this light, poverty alleviation policies should be geared to expanding people's opportunities to pursue goals they value. Income shortage, then, becomes just one dimension of poverty, and is neither the sole content nor the leading cause of it. Furthermore, Sen's approach perceives the dimensions of poverty (such as malnutrition, illiteracy, etc.) as developmental ends in themselves, and not simply as means to a preconceived goal, such as enhancing productivity (Sen, 1992). In the context of urban development (to anticipate), this approach offers an opportunity to policy-makers to break with the dualistic tradition by moving towards a more integrated understanding of the relationship between poverty and squatter settlements.

While Sen's approach has identified the need to expand the conceptualization of poverty beyond the dimension of income deficiency, he has not specified an inflexible list of valuable capabilities or functionings. Sen's capability approach is deliberately incomplete with respect to such lists because it recognizes that what is centrally important can be spatially and inter-personally variable (Alkire and Black, 1997). Thus the concept of poverty can be understood to be absolute when it is viewed as capability deprivation, but relative in so far as the list of valued capabilities has to be contextualized.

Sen does not propose an operational guideline to select and measure capabilities (Robeyns, 2003). Rather, he emphasizes the need for democratic processes to identify the list of valued capabilities that are context-sensitive and culture-sensitive. This perception of people as sources of information and agents of change is another concept of Aristotelian origin. According to Sen, "the people have to be seen, in this (development as freedom) perspective, as being actively involved - given the opportunity - in shaping their own destiny, and not just as passive recipients of the fruits of cunning development programs" (Sen, 1999, p. 53). 
The openness of Sen's approach has attracted the criticism that it is incomplete and unspecified (Nussbaum, 1988; Doyal and Gough, 1991). Nussbaum (2000) has argued that it is necessary to have a list of 'functional capabilities' to ensure that the process of public deliberation does not lead to the expansion of 'negative' capabilities. Some scholars have tried to come up with a broad and universal list of capabilities that can be shared by different cultures. Consensus on the list has been hard to reach, as reflected in context-specific variations in identified capabilities and the weights attached to these (Clark, 2003; Gigler, 2005). There is reason to believe that the openness of Sen's approach is a strength, rather than a weakness; it provides an inclusive conceptual framework that captures the multiplicity and diversity of the perception of human well-being.

Participatory methods become an important tool for the contextualization and operationalization of Sen's approach, as has been argued by Alkire (2002). Alkire proposes Ellerman's (2001) 'autonomy-compatible' model as a means of integrating participatory elements into the capability approach, and ensuring that doers are in the driving seat of development projects. Crocker also expands on the links between participation and the capability approach by arguing that the theory of deliberative democracy offers “... a principled account of the processes groups employ to decide certain questions and form their values" (Crocker, 2006, p. 4). By choosing and weighting valuable capabilities and functionings through participatory methods, the capability approach can aim at improving people's ability to escape poverty, while still preserving and expanding their social and cultural identities (Ellerman, 2001).

\section{The capability approach: application to urban development}

In the context of squatter upgrading projects, Sen's approach should generate interventions that defer to, while optimizing on, the already existing processes of urbanization. By acknowledging and utilizing the available resources of squatter dwellers, and removing the obstacles to the expansion of their valued freedoms, the local dynamics of emergence from poverty can be supported and enhanced. "If you have to decide what has to be done in the slums it is not a question of what the slum dwellers need - you have to find what they could do if they had the freedom to do it" (Sen, 2002, cited in Khosla and Samuel, 2005, p. 70). Imposed processes could destroy the existing capabilities possessed by dwellers and aggravate the difficulty encountered by the poor in emerging from their poverty. In other words:

Sustainable poverty elimination will be achieved only if external support focuses on what matters to people, understands the difference between groups of people and works with them in a way that is congruent with their current livelihood strategies, social environment and ability to adapt. (Carney et al., 1999, p. 8) 
The potentials of cultural identity have also been emphasized in Khosla and Samuels' (2005) application of Sen's ideas to the context of urban development. The authors argue that the increasing enactment of urban laws, which encourage a global monoculture city, has the effect of suppressing the identity of migrants and enhancing their unfreedoms. "For example in physical formations, these restrictions are related to the type of housing that is acceptable and to the use of open spaces for social uses. $[\ldots]$ The restrictions enforced to maintain a stylistically uniform city are coercive because such regulations tend to obliterate the multiple distinctions and visions that the wide range of migrants value as part of their own identities" (Khosla and Samuel, 2005, p. 19). Urban programmes with the objective of enhancing people's freedoms should, rather, be engaged in identifying the underlying physical designs of the built environment and expanding the successful expression of these cultural values (Khosla and Samuel, 2005).

By applying Sen's thinking to an urban development context, it is possible to identify an emerging paradigm that moves away from a dualistic perception of cities (formal and informal; included and excluded) to one based on freedoms, interaction, multiplicity and diversity. Of related interest is a call, issued by some commentators, for an approach that can break from the enlightenment positivist epistemology of conceptualizing cities. These critiques “ $\ldots$ contain powerful attacks on the concepts of technical rationality, objective knowledge, critical distance; notions of progress and enlightenment; they embrace multiple discourses and reject totalizing ones; and they propose a shift from linear time and physically inert space to new ways of conceiving of space and time, dialectically, socially, and historically" (Sandercock, 1998, p. 29). Sandercock proposes an epistemology of multiplicity for planning practice based on multiple ways of knowing, including local experiental and intuitive knowledge (Sandercock, 1998). Thus, in an urban development context, there is space for an approach that can conceive urban interventions as an expansion of the dynamics of multiplicity and diversity. Sen's thinking, as applied to the urban context, has the potential for serving as a coherent, open, and inclusive framework that can be contextualized and concretized by local dynamics and priorities.

However the application of the freedom discourse to the urban development context is not necessarily a novel approach. Turner used the same vocabulary freedom to build in his classical study Housing as a Verb (Turner, 1972). During the 1970s, Turner's self-help approach became the dominant housing strategy of international agencies. On the one hand there are similarities between the writings of both authors (i.e. Sen and Turner): people are perceived as agents of change, and not mere recipients; commodities are analysed by what they do to people's lives and not by what they are. On the other hand, there are significant differences between the two authors in the manner of conceptualizing freedom. Turner's perception of freedom focuses on negative freedom, or 
liberty. It is concerned with 'absence of impediments' and freedom from state interference. Meanwhile, Sen has developed a much more elaborate perception of freedom, which embraces also its positive aspects, such as choice, power and autonomy. In other words, Sen goes further than Turner by focusing not only on the idea of 'freedom from', but also on that of 'freedom to', by strengthening those "... supportive influences which actually help a person to do the things that she wants to do" (Drèze and Sen, 2002, p.61). A proper elaboration of the links between the two authors would require a fuller account than can be accommodated in the present paper.

This short review of the capability approach suggests that, if one perceives 'development as freedom', squatter upgrading programmes should focus on the expansion of dwellers' capabilities. This approach recognizes that the poor have resources and strategies for emerging from poverty. Thus the role of upgrading programmes should be to give fuller expression to these available strategies, and to remove the obstacles that constrain the dwellers' ability to emerge from poverty. In this perspective, the cultural identities that are a part of squatter settlements should be recognized and maintained, because they constitute a part of the few resources available to the settlements' dwellers. Furthermore, since squatter dwellers are recognized as active agents of change, they should assume the dominant role in any upgrading project, in which pre-existing democratic organizations can be enhanced and empowered. Sen's thinking therefore opens up an opportunity for urban theorists and planners to break from the enlightenment positivist epistemology and accept the dimensions of multiplicity and movement in conceptualizing urban policy. Even though Turner has used the concept of freedom in the urban context in his self-help approach, Sen's writings offer significant innovations by exploring the nature of well-being and the positive aspects of liberty. The next section will look, first, at how the World Bank has translated Sen's concepts, and, subsequently, at how it has influenced squatter upgrading strategies.

\section{The World Bank and urban policies for the twenty-first century}

There is reason to discern a certain movement on the part of the World Bank, at least at the level of statement of intent, towards an acceptance of Sen's views on deprivation. The Bank's shift from the market-orientated conceptualization of poverty to one embracing new dimensions is epitomized in the article (cited earlier) by Wolfensohn and Sen (1999). A 'friendly' developmental approach is proposed to enhance people's freedom to avoid not only economic but also social deprivations.

These freedoms are both the primary ends and the principal means of development. They include freedom to participate in the economy, which implies access to credit, among other 
facilities; freedom of political expression and participation; social opportunities, including entitlement to education and health services; transparency guarantees, involving freedom to deal with others openly; and protective security, guaranteed by social safety nets, such as unemployment insurance or famine relief. (Wolfensohn and Sen, 1999)

The Bank's move toward a more expansive conceptualization of poverty is confirmed in the 2000/2001 World Development Report (World Bank, 2000a), in which the Bank incorporates in its conceptualization of poverty the views of poor people, as expressed in the World Bank study Voices of the Poor (World Bank, 1999). The definition of poverty is expanded to include "powerlessness and voicelessness, and vulnerability and fear" (World Bank, 2000a, p. 5).

Poverty is much more than income alone. For the poor, the good life or wellbeing is multidimensional with both material and psychological dimensions. Wellbeing is peace of mind; it is good health; it is belonging to a community; it is safety; it is freedom of choice and action; it is a dependable livelihood and a steady source of income; it is food. (World Bank, 2002)

The language of policy certainly seems to suggest a reorientation in the Bank's approach to the conceptualization of deprivation. But the interesting question is whether there has been any substantial change in the content of policy. Evidence of a certain distance between language and content becomes clearer from a study of the Bank's 'new' 'framework for action' in the 2000/2001 World Bank Report, which calls for comprehensive and inclusive development, in which the poor would have more decision-making power, greater security, and greater latitude of opportunity at the local level (World Bank, 2000a). The Bank argues that the 1990s framework for action was too limited to encourage development; investing in social services and human capital had not been enough to secure economic development. The Report calls for focusing on three areas: promoting opportunity, facilitating empowerment and enhancing security. The first is concerned with introducing market reforms targeted at poor people. Empowerment is concerned with enhancing the capacity of poor people to participate in the political process - but it also means " ... removing the barriers - political, legal and social - that work against particular groups and building the assets of poor people to enable them to engage effectively in markets" (World Bank, 2000a, p. 39). Finally, security means reducing the vulnerability of the poor to risks such as ill health, economic shocks, and natural disasters. By targeting these three areas, the content of policy both preserves the earlier emphasis on market orientation, and expands the Bank's sphere of influence on governance restructure while scaling down the focus on provision of social services.

Compatible with the above is the observation that the World Bank's squatter upgrading strategies began to focus even more on a city 
development strategy, rather than just the provision of social services or enhancing productivity of the housing sector. An Alliance between the World Bank and UN-Habitat was formed in 1999, with the responsibility for distributing loans, along with appropriate recommendations, to tackle urban poverty in developing countries The Alliance's 2003 annual report called for an attack on urban poverty by focusing on two areas: city development strategy (CDS), and citywide and nationwide squatter settlement upgrading (Cities Alliance, 2003). Again, the language of policy is beguiling. In line with the objectives flagged in the 2000/2001 World Development Report (World Bank, 2000a), the Alliance visualizes that city and nationwide squatter settlement upgrading must involve dwellers and the private sector in the decision-making process and mobilization of resources. The content of policy, however, still retains much of the flavour of an earlier vintage. Policies of the 1990s - such as urban land reforms, targeted subsidies, expansion of infrastructure and services, and competitive housing finance - which enable housing markets to prosper, continue to be encouraged. Additionally, there is a suggestion of the need for policies to reflect an enhanced focus on participation from all actors in all spheres of activity. While the poor are called upon to participate in the decision-making process as well as in the mobilization of resources, the operational aspect of 'participation' seems to reside in the recommendation that non-governmental organizations (NGOs) and the private sector should play a stronger role in the delivery of services (Cities Alliance, 2003).

Meanwhile, the Alliance envisages CDS as a mechanism to create a shared vision of the city's future among all stakeholders. While acknowledging the need for each city to develop its CDS, the Alliance also identifies clear goals and outcomes such as policy, governance, and institutional reforms for raising the productivity and competitiveness of cities. By 'enabling a better business environment', the CDS hopes to 'mobilize additional investments' to the city. While housing sector policies are now recommended for all spheres of city governance, the recommendations go far beyond the housing sector: "Linkages between the city and major national investment programmes in the port, airport, and the free zone are essential for attracting investment to expand employment and services as well as for providing quality and adequate basic services to both citizens and investors" (Cities Alliance, 2003, p. 11).

The World Bank vision of urban development is further explained in the 2000 World Bank strategy paper on urban and local government (World Bank, 2000b). This paper also shows how policies have not shifted in direction, but rather applied their market-orientated ideology to new dimensions. Again, the language-content contrast in policy discourse is interesting. The strategy paper adapts the new dimensions of poverty to an urban context by arguing that "urban poverty entails a sense of powerlessness, and an individual and community vulnerability, that undermines human potential and social capital" (World Bank, 2000b, 
p.3) The strategy dictated by this more expansive understanding of development is one that will encourage the notion of a sustainable city:

The ultimate aim of this strategy is to promote sustainable cities and towns that fulfil the promise of development for their inhabitants - in particular, by improving the lives of the poor and promoting equity - while contributing to the progress of the country as a whole. (World Bank, 2000b, p. 6)

But what does 'sustainability' imply? Further on in its policy paper, the Bank clarifies its vision of sustainable cities. To become sustainable, cities need to be liveable, competitive, well governed and managed, bankable. Liveability is concerned with living standards. Squatter settlement upgrading is proposed as the mechanism for tackling lack of infrastructure, as well as powerlessness and vulnerability. Powerlessness can be tackled by "... addressing constraints to small-scale and informal sector enterprise ..." (World Bank, 2000b, p. 8). Meanwhile, vulnerability is also conceptualized in economic terms, since market-sensitive urban planning methods are advanced to help cities to cope with multiple crises that could constrain growth. The competitive variable is concerned with the "... basic conditions for urban productivity, which are also necessary to make cities competitive and entrepreneurial in the global marketplace" (World Bank, $2000 \mathrm{~b}$, p.9). Improving governance and management of cities entails, among other things, fulfilling public responsibilities by enhancing private sector participation and facilitating public-private partnerships. The concept of a bankable city relates to the notion of creditworthiness, permitting access to city loans. "Integrating informal and marginal communities as full urban citizens, taxpayers, and public service customers, is therefore an important goal" (World Bank, 2000b, p. 11). The Bank's view on sustainable cities is clearly market-orientated. The new dimensions of the conceptualization of cities have expanded market ideology into new spheres, and it is hard to resist the view that market enablement is still the Bank's development strategy. The old-wine-in-anew-bottle impression gains additional plausibility from a consideration of the following excerpt from the Bank's strategy paper:

An important part of good urban financial management involves adopting a commercial approach to many of the service and administrative functions of cities, while keeping social concerns in view. A commercial approach is also a prerequisite for involvement of the private sector or eventual privatization of urban services. (World Bank, 2000b, pp. 11-12)

The Bank concentrates its analysis of squatter upgrading policies on the relationship between improvements and the city's macro-economic conditions. The tendency is to blame all failures to raise the city's productivity on the government's inability to make markets prosper. Proffered solutions have become less specific and more general, with a 
shift from an earlier project focus to a housing sector focus to a CDS. However, little attention is paid to operational aspects of the squatter upgrading policies, and to how solutions on the ground, shaped by the shifts in focus, will affect the lives of the squatter dwellers. The language of World Bank policy is strong on freedom, but there is little engagement with whether the content of the Bank's policy will enhance or constrain the freedom of city dwellers to emerge from poverty. To address this question would require a study of an actual city upgrading project. The next section offers some preliminary evidence of the impacts of the World Bank's squatter upgrading programme in the city of Salvador da Bahia in Brazil.

\section{A case study of Salvador da Bahia, Brazil}

Since the abolition of the BNH in 1986, and the drawing up of a new Constitution in 1988, state governments rather than the national government in Brazil became responsible for solving the problem of growing squatter settlements. This process of decentralization of responsibilities also resulted in a decentralization of loans. World Bank loans targeted state governments rather than the national government. Through its conditionality clauses, the Bank increased its influence on state governments' policy-making. The state of Bahia became a major recipient of the Bank's loans, and Salvador the recipient of a comprehensive neo-liberal package designed to transform it into a liveable, competitive, well managed and bankable city. The most recent agreement signed by the state government of Bahia and the World Bank in 2003 arranged a US\$98million loan to scale up the squatter upgrading programme called Ribeira Azul.

The area denominated Ribeira Azul covers $4 \mathrm{~km}^{2}$, with a total population of 135000 dwellers. This is equivalent to six per cent of the total population of Salvador, and 21 per cent of squatter dwellers of the city. The first intervention in the area took place in 1976, when the national government funded an upgrading project to tackle the growing number of houses on stilts in the area. The project replaced the houses on stilts with basic shelter and infrastructure. However the houses on stilts came back and the area became one of the most deprived regions of Salvador. According to the 2000 national census, there are areas within Ribeira Azul where nearly 90 per cent of the working population earns between zero and two minimum salaries ${ }^{2}$ per month. The percentage of squatters with sewage connections can be as low as five per cent In 1992, the state government together with an Italian NGO - Associazione Volontari per il Servizion Internazionali (AVSI) - drew up plans for a new intervention in the area called Novos Alagados. In 1996 the Pilot project was concluded and, according to the state government, 8000 people were benefited by the project with better housing, infrastructure and social services. The pilot project has been accepted by the local 
community leaders, AVSI and the state government as innovative due to its unprecedented participatory approach.

Already in 1996 the state government had begun taking the first steps to scale up the Novos Alagados project into the Ribeira Azul programme, which would reach 10 squatter settlements in the area. In 2000, the second stage of the project was already taking place, and in 2001 resources for the project totalled US $\$ 60$ million. This included a US $\$ 5$ million donation from the Italian Government, a direct loan from the World Bank, funding from the state, and funding from the federal government (which gets its resources from the International Development Bank). The programme has concluded its second stage and the third, fourth and fifth stages are being currently implemented. As mentioned previously, in 2003 the Bank agreed to loan another US $\$ 98$ million to further extend the programme. The Ribeira Azul programme has been perceived by Cities Alliance and the World Bank as a great success, due to its innovative architecture and participatory approach (Imparato and Ruster, 2003).

However, an evaluation based on the capability approach reveals a more ambiguous result. In assessing the impact of the programme, it is useful, first, to identify certain local 'dimensions of human flourishing' in the housing context, and to see how these dimensions have been affected. Basing her study on Finnis (1980), Alkire argues that “... dimensions of human flourishing represent the basic values people are seeking when they 'be and do and have and interact' - morally or immorally" (Alkire, 2002, p. 74). Alkire believes that "the purpose of identifying such dimensions $[\ldots]$ is to offer a framework within which different values that communities have may be understood (within which, therefore, our informational base of social welfare may be expanded) ..." (Alkire, 2002, p. 53). ${ }^{3}$ Sen also proposes a list of five instrumental freedoms that “... contribute, directly or indirectly, to the overall freedom people have to live the way they would like to live" (Sen, 1999, p. 38). The extent to which the five instrumental freedoms (political freedom, economic facilities, social opportunities, transparency guarantees and protective security) are secured is informative about the level of development of an individual, household, or community (Sen, 1999).

It is instructive to adapt Sen's and Alkire's typologies to the particular case study of this research, as an aid to unfolding the instrumental freedoms that shape the ability of the dwellers of Novos Alagados to extricate themselves from poverty and improve their housing conditions. The specific list of dimensions of human flourishing employed in this study is based on the perceived specificities of the context at hand: as in the case of Sen and Alkire, there is no recourse to a presumed universal list shaped by universal values. This 'incompleteness' is seen in the present study as a major strength of the capability approach, one that permits an application of the approach to different contexts with different variables without losing its philosophical essence. After undertaking informal interviews with local dwellers and academics, given the local context, six 
instrumental freedoms (or dimensions of human flourishing) emerged as essential requirements for a person to be sheltered in a dignified way: the freedom to individualize, the freedom to expand, the freedom to afford living costs, the freedom to have a healthy environment, the freedom to participate, and the freedom to maintain social networks (see Table 2).

A short and preliminary assessment of the Ribeira Azul programme focuses on the impacts the programme has had on each of the freedoms identified. Through a participatory approach (using focus groups and semi-structured interviews), this assessment aims to discover the impacts of the upgrading programme on the dwellers' freedom to acquire dignified shelter.

\section{Freedom to expand and individualize}

The process of individualization of the structure and the design of shelters in the squatter settlements is part of their cultural identity, which reflects social, economic and political features of the population in the built environment. The freedom to individualize and expand has been one of the dwellers' assets, which allowed them to improve their quality of life affordably and within the same environment. This dimension has a direct parallel to Alkire's dimension of practical reason and self-integration, which “... regards the freedom a group has to exert self direction: to create and sustain their identity even if it differs from the identity of the funding agency, for example" (Alkire, 2002, p. 283). Santana (1994) argues that dwellers show awareness of the aesthetic condition of their houses by improving them and adding floors. Often, even before the first floor is completed, a second floor is already under construction. Severo (1999) explains that this process represents the dwellers' aspiration to distinguish themselves from other dwellers and improve their social status. Informal interviews with dwellers from the area of the Ribeira Azul programme revealed that their main critique of the upgrading programme is that it does not allow them to expand their houses as they wish. Residents of the second stage of the programme are not permitted to change their house design and structure. Even if they were allowed to, the actual structure of

Table 2. Adaptation of previous lists of dimensions of human flourishing

\begin{tabular}{|c|c|c|}
\hline Adapted list & $\begin{array}{l}\text { Alkire's (2002) dimensions of } \\
\text { human flourishment }\end{array}$ & $\begin{array}{l}\text { Sen's (1999) instrumental } \\
\text { freedoms }\end{array}$ \\
\hline Freedom to expand & Practical reason/self-integration & Social opportunities \\
\hline Freedom to individualize & Practical reason/self-integration & Social opportunities \\
\hline Freedom to afford living costs & Work/play & Economic freedom \\
\hline $\begin{array}{l}\text { Freedom for healthy } \\
\text { environment }\end{array}$ & Life/health/security & Protective security \\
\hline Freedom to participate & Practical reason & Political freedom \\
\hline $\begin{array}{l}\text { Freedom to maintain social } \\
\text { network }\end{array}$ & Relationships & Transparency guarantees \\
\hline
\end{tabular}


the houses would not help the expansion to take place. Nevertheless, residents have been individualizing their houses illegally. Eduardo Teixeira, one of the mentors of the 1976 upgrading programme, warned that by not accepting this dynamic of the dwellers, the houses could become a source of serious conflicts between residents.

\section{Freedom to afford living costs}

For any upgrading programme to be successful, it is necessary to ensure that dwellers can afford the living costs of the houses in which they are relocated. Sen and Alkire have included in their list the economic variable (economic facilities and work/play, respectively). As explained by government officials, one of the main objectives of the Ribeira Azul programme was to resettle the dwellers in the same area. As the location is favourable due to its proximity to the city centre, dwellers did not have to confront increased transport costs. Meanwhile, local cooperatives were used to build the houses, and funds were allocated for running courses to train electricians and builders. Dwellers acknowledge that these initiatives generated employment for members of the community, which helped to raise residents' income. On the other hand, costs increased significantly for the residents of the new houses, since they had to pay for electricity and water, and a monthly instalment toward 15 per cent of the cost of their new houses. Many households could not afford the new expenses and once again acquired their electricity through illegal connections. Furthermore, none of the residents complied with payment of the monthly instalment. While residents' costs have increased, many of them have not benefited from the employment generation opportunities.

\section{Freedom for a bealthy environment}

This freedom is a direct parallel to Alkire's categories of life/health/security and Sen's intrinsic freedom of social opportunities, which "refer to the arrangements that society makes for education, health care and so on, which influence the individual's substantive freedom to live better" (Sen, 1999, p. 39). From the time of its inception, the environmental improvements associated with the programme at Novos Alagados have been significant. All the houses on stilts were removed and dwellers were placed in houses of 22 or $44 \mathrm{~m}^{2}$. The population density per square meter has decreased considerably. A rubbish collection point was placed within the residential area and close to the motorway, which ensured easy access for the community and bin collectors. All the houses were handed over with connections to the basic services (electricity, water and sewage). Meanwhile, an NGO received funds to run a project to improve the nutritional habits and hygiene of the local population. The pilot project began in 2002, involving 60 undernourished children and their mothers. The ambition of the NGO is to reach 700 children. Despite all these 
improvements, there is one basic deficiency that underlies the programme: the space available in a house, which is a source of major dissatisfaction for many of the residents. According to Emiliano José, a local councillor and journalist, $22 \mathrm{~m}^{2}$ are unacceptably small since it forces dwellers to live in a 'promiscuous agglomeration'. Residents cannot accept the fact that they are being asked to pay for a house that is a half of the size of the house on stilts they used to have. Many residents are determined to expand their houses, even without government authorization, because the dwelling space available to them is inadequate for dignified habitation.

\section{Freedom to participate and to maintain social networks}

While the freedom to participate has a parallel to Sen's political freedom, the freedom to maintain social networks is a direct parallel to Alkire's dimension of 'relationships'. Political freedom, broadly conceived, "refers to the opportunities that people have to determine who should govern and on what principles ..." (Sen, 1999, p. 38). Alkire's dimension of 'relationships' refers to how people interact in a community and its impact on friendship, tolerance, security and trust. In the Ribeira Azul context, the freedom to participate in, and maintain, existing social networks are the most controversial issues of the programme. Government officials indicate that, due to pressure from the World Bank, these two issues are projected as having high priority in the programme. By placing residents close to their neighbours from their previous shelter, the Bank believed social network strategies would be maintained. Meanwhile, to increase participation, every street selected a street leader who would form a council that would meet regularly with technicians, NGOs and government officials. Government officials argue that this was necessary because the communitybased organization, Primeiro de Maio, was influenced by the opposition party and it did not represent most of the dwellers from the area. According to Benedetta Fontana, coordinator of the social programmes led by the Italian NGO AVSI, such an approach aimed at creating new leaderships to encourage participatory intervention.

Criticisms of Ribeira Azul's participatory strategy came from residents, community leaders, scholars and local councillors. Interviews with community leaders from other squatter settlements in Salvador revealed that any attempt to create local leaders could prove unsuccessful, since leaders have to emerge from within the community and not through a process imposed by outsiders. This can be one of the reasons why, out of 49 elected street leaders, only two remain active. According to a leading member of the community-based organization Primeiro de Maio, the council had a consultative role and no decision-making power. Furthermore, the same person believes that Ribeira Azul has tried to weaken Primeiro de Maio; ${ }^{4}$ firstly by not acknowledging it as an active NGO and therefore not providing for its funding, and secondly by trying to create new leaderships and NGOs to weaken and replace the strong 
community organization. In this view, participation has been manipulated and co-opted to elicit acceptance of the preconceived goals established by the government officials and the World Bank. According to local councillor Emiliano José, "Novos Alagados fought for a worthy housing project, not for propaganda and bureaucracy, not for this project about which the population has not been asked its opinion and which it does not accept" (Emiliano, 2001). Such an evaluation has obvious implications for dwellers' freedom to participate in the decision-making process, and for their ability to maintain social networks in a situation where the community's strongest organization is being threatened.

This preliminary evaluation of the Ribeira Azul programme suggests that the World Bank did try to address some of the freedom-related problems reviewed above. However, the Bank's approach to the issue would appear to be significantly different from what the capability approach would warrant. The expansion of personal freedom has been compromised to a substantial extent by the failure to take sufficient stock of the existing dynamics of urban culture. The problem has been compounded through privatization of services, the maintenance of strong urban regulations, and the unwelcome imposition of a housing aesthetic.

\section{Conclusion}

Many recent pronouncements of the World Bank suggest that the new millennium has marked a shift in its traditional conceptualization of poverty to one based on Sen's conceptualization of the phenomenon in terms of 'capability deprivation', with an attendant emphasis on the notion of 'development as freedom'. It would also appear that, in particular, this re-orientation is a feature of the Bank's perspective on urban development. Such at least is the impression one receives from a study of selected documents and policy strategy papers put out by the World Bank.

However, a closer scrutiny of the World Bank's policy orientation suggests that there is some disjuncture between the language of policy and its content. The goals of development as set out by Sen are accepted, but also seen as being best served by policies that continue to place major emphasis on market enablement and an income-centred approach to development.

This paper, apart from reviewing certain basic aspects of Sen's capability approach at a general level, has also sought to apply his ideas to the particular context of urban development. An assessment of the World Bank's policy thrust on urban development, in the light of what the capability approach might have warranted, strongly suggests that the Bank's 're-orientation' is largely a victory of form over substance, and of deferment to a framework of ideas that is poorly reflected in its application. This impression is fortified by the preliminary results of an evaluation of a Bank-sponsored squatter upgrading programme in the Brazilian city of Salvador da Bahia. The evaluation suggests that the 
upgrading programme fails to satisfy a basic requirement of the capability approach - that of protecting and promoting the freedoms of the principal agents in need of benefiting from the developmental process. In particular, it would be a misreading of this approach to imagine that it attaches greater urgency to securing an investor's freedom to develop urban markets than to securing an impoverished city-dweller's freedom to shift out of poverty and into a habitation that provides dignified shelter.

\section{Acknowledgements}

The author would like to thank the Foundation of Urban and Regional Studies for funding his Ph.D. project, which generated the information for this paper. The author would also like to thank the anonymous referees for their detailed comments and the people that contributed to this research in a variety of ways, including academics, community leaders and squatter inhabitants. Particular thanks are due to Ph.D. supervisor Roger Zetter for his continuous advice, support and inspiration.

\section{Notes}

1 The other major donor influencing the Brazilian government in its housing strategies has been the Inter-American Development Bank. However, this paper will focus on the work of the World Bank, as it is the major donor influencing the urban policies of the state of Bahia.

2 In March 2006 the rate of the Brazilian minimum salary per month was $R \$ 300$ (Ministerio da Fazenda, 2006), which is equivalent to US\$140 (20 March 2006).

3 Sabina Alkire's list of dimensions of human flourishing proposes a modification of Finnis' list, comprising life, knowledge, meaningful work/play, relationships, religion, self-integration or inner peace, participation or practical reason, art and aesthetic appreciation, and the environment (Alkire, 2002, p. 73).

4 Primeiro de Maio is one of the strongest and most active community organizations in Salvador. It runs a wide range of projects, such as technical courses for young people, kindergartens, and generation of employment through a local publishing unit.

\section{References}

Alkire, S. (2002) Valuing Freedoms. Sen's Capability Approach and Poverty Reduction, Oxford University Press, New York.

Alkire, S. and Black, R. (1997) 'A practical reasoning theory of development ethics: furthering the capabilities approach', Journal of International Development, 9, pp. 263-279.

Carney, D., Drinkwater, M., Rusinow, T., Neefjas, K., Wanmali, S. and Singh, N. (1999) Livelihoods Approaches Compared, Department for International Development, London.

Chiappero Martinetti, E. (2000) 'A multi-dimensional assessment of well-being based on Sen's functioning theory', Revista Internazionale di Scienza Soziali, CVIII(2), pp. 107-239.

Cities Alliance (2003) Cities Without Slums - 2003 Annual Report, Cities Alliance, Washington, D.C. 
Clark, D.A. (2003) 'Conceptions and perceptions of human well-being: some evidence from South Africa', Oxford Development Studies, 31, pp. 174-196.

Crocker, D. (2006) 'The capability approach and deliberative democracy', Briefing of the Human Development and Capability Association, 4, pp. 4-6.

De Soto, H. (1989) The Other Path, Harper and Row, New York.

De Souza, F.A.M. and Zetter, R. (2004) 'Urban land tenure in Brazil: from centralized state to market processes of housing land delivery', in R. Zetter and M. Hamza (Eds), Market Economy and the Urban Change: Impacts in the Developing World, Earthscan, London.

Doyal, L. and Gough, I. (1991) A Theory of Need, Macmillan, London.

Drèze, J. and Sen, A. (2002) India: Development and Participation, 2nd edition, Oxford University Press, Oxford.

Ellerman, D. (2001) 'Helping people help themselves: autonomy-compatible assistance', in Hanna, Nagy and Picciotto, Robert (Eds), The New Development Compact: Toward a Comprehensive Strategy, The World Bank, Washington, D.C.

Emiliano, J. (2001) Querem Perpetuar a Favela [http://emilianojose.com.br/texto_ discursos_41.htm] (accessed April 2001).

Finnis, J. (1980) Natural Law and Natural Rights, Clarendon Press, Oxford.

Gigler, B. (2005) 'Indigenous peoples, human development and the capability approach', paper presented at the 5th International Conference on the Capability Approach, Paris.

Gordilho, S.A. (2000) Limites do Habitar - Segregação e Exclusão na Configuração Urbana Contemporânea de Salvador e Perspectivas no final do século $X X$, EDUFBA, Salvador.

Gore, C. (2000) 'The rise and fall of the Washington Consensus as a paradigm for developing countries', World Development, 28, pp. 789-804.

Imparato, I. and Ruster, J. (2003) Slum Upgrading and Participation: Lessons from Latin America, The World Bank, Washington, D.C.

Instituto Brasileiro de Geografia e Estatística (2004) [http://www.ibge.gov.br] (accessed August 2004).

Khosla, R. and Samuel, J. (2005) Removing Unfreedoms. Citizens as Agents of Change in Urban Development, ITDG Publishing, London.

Lewis, O. (1966) La vida, Random House, New York.

Martinez, C.C. (1988) 'Pobreza Urbana: Problemas de Ordem Conceitual e implicações da Política', Seminar on Urban Poverty, World Bank, Rio de Janeiro.

Ministerio da Fazenda (2006) Salario minimo nominal 1940/2006 [http://www.mte.gov.br/ EstudiososPesquisadores/SalarioMinimo/Conteudo/MI NIMO01.pdf] (accessed July 2006).

Nussbaum, M. (1988) 'Nature, functioning and capability: Aristotle on political distribution', Oxford Studies in Ancient Philosophy, Supplementary Volume, pp. 145-184.

Nussbaum, M. (2000) Women and Human Development: The Capabilities Approach, Cambridge University Press, Cambridge.

Robeyns, I. (2003) The Capability Approach: An Interdisciplinary Introduction, [http:// www.ingridrobeyns.nl/] (accessed December 2003).

Sandercock, L. (1998) Towards Cosmopolis, Wiley, Chichester.

Santana, M.R.C. (1994) O cotidiano da Verticalização de Favelas: Uma alternative Habitacional em Salvador, UFBA, Salvador.

Sen, A. (1992) Inequality Re-examined, Clarendon Press, Oxford.

Sen, A. (1996) 'On the foundation of welfare economics: utility, capability and practical reason', in Francesco Farina, Frank Hahn and Stefano Vanucci (Eds), Ethics, Rationality and Economic Behavior, Clarendon Press, Oxford.

Sen, A. (1999) Development as Freedom, Oxford University Press, Oxford.

Sen, A. (2002) 'Agents of change', discussion document from an interview at Cambridge, filmed by TVE.

Severo, G.D. (1999) Impactos Ambientais em area de ocupação espontânea: o exemplo do Calabar, UFBA, Salvador.

Turner, J.F.C. (1972) Housing as a verb, in J.F.C. Turner and R. Fichter (Eds), Freedom to Build, The Macmillan Company, New York. 


\section{A. A. Frediani}

Wade, R. (2001) 'Showdown at the Bank', New Left Review, 7, pp. 124-137.

Wolfensohn, J.D. and Sen, A. (1999) Development: A Coin with Two Sides, [http://web.worldbank.org/WEBSITE/EXTERNAL/EXTABOUTUS/ORGANIZATION/ PRESIDENTEXTERNAL/0] (accessed January 2003).

World Bank (1999) Poverty Trends and Voices of the Poor, The World Bank, Washington, D.C.

World Bank (2000a) World Development Report 2000/2001, The World Bank, Washington, D.C.

World Bank (2000b) Cities in Transition - World Bank Urban and Local Government Strategy, The World Bank, Washington, D.C.

Word Bank (2002) Voices of the poor - listen to the voices. [http://www1.worldbank.org/ prem/poverty/voices/listen-findings.htm\#1] (accessed May 2004). 